\title{
The ontological characteristics of the Church of Jesus Christ of Latter-day Saints
}

\author{
Nursulu Sauranbekkizi Altayeva ${ }^{1}$, Kairat Aitbekovich Zatov ${ }^{2}$, Kakimzhan \\ Muratzhanovich Bishmanov ${ }^{3}$, Kudaiberdi Bagasharov ${ }^{4} \&$ Mukan Nurzat $^{5}$ \\ ${ }^{1}$ Al-Farabi Kazakh National University, 71 al-Farabi avenue, Almaty, Republic of Kazakhstan \\ ${ }^{2}$ Egyptian University of Islamic Culture "Nur-Mubarak", \\ ${ }^{3,4,5}$ Al-Farabi Kazakh National University, 71 al-Farabi avenue, Almaty, Republic of \\ Kazakhstan.
}

\begin{abstract}
:
The article analyzes the main principles behind the ontological doctrine of the Church of Jesus Christ of Latter-day Saints, as well as the characteristics of its genesis, development and functioning in a Protestant environment. The work provides a basic definition of ontology as the science of being, determines its conceptual content in the religious dimension and characterizes essential moments of the sacral history of the Universe and mankind from the perspective of Mormonism that are essential for the study of the ontological aspects of this belief system. The research is accompanied by comparative analysis of the ontological doctrine of the Church of Jesus Christ of Latter-day Saints and philosophical systems that have directly or indirectly influenced the Mormons' worldview, including G. Leibniz's monadology, Aristotle's first principles and Plato's theory of ideas. At the same time, the authors identify the specific features of monotheistic ideas in the doctrine of Mormonism and its difference from other monotheistic beliefs. Fundamental ontological categories, such as movement, time, space, spirit and matter are analyzed through the prism of Mormon perception.
\end{abstract}

Keywords: Church of Jesus Christ of Latter-day Saints, Mormons, ontological doctrine, monotheism, movement, matter, spirit, Neo-Christianity, ontological categories, religious denominations.

\section{Introduction}

The specific features of Neo-Christian movements are connected with the search for new effective instruments for the satisfaction of spiritual needs of a modern person coming from the Western world. These movements emerge predominantly in the Protestant environment and combine plenty of elements of various religions and cults, adding something new to this amalgam. The rapid development of the modern religious network allows anyone to choose the belief system that is the closest for them in terms of their views of life, religious paradigm, a well as psychological and social motivation. (Šindleryová and Bačuvčík 2019).

Taking into account the psychological component, the motivation for such intention is the wish to renew Christianity without shaking its existing foundations (Abylaikhan, Karmanova, Abilkassimova, Beisenbekova and Baizhumanova 2019). Advanced philosophical ideas and

(C) AesthetixMS 2020. This Open Access article is published under a Creative Commons Attribution Non-Commercial 4.0 International License (http://creativecommons.org/licenses/by-nc/4.0/), which permits non-commercial re-use, distribution, and reproduction in any medium, provided the original work is properly cited. For citation use the DOI. For commercial re-use, please contact editor@rupkatha.com. 
scientific discoveries in physics, astronomy, biology and other spheres have significantly modified the worldview of modern people, but they do not want to lose the solid Christian basis. Instead, they change the ontological doctrine, which they perceive as outdated.

The Church of Jesus Christ of Latter-day Saints (the LDS Church) is the largest and most influential denomination among all other representatives of the Neo-Christian world. It sets the direction for scientific, social and business activities of its institutions in line with its own ontological characteristics. Having four universities, scientific laboratories, research and development enterprises, research centers and over 16 million believers all over the world, the Church is already a power that is gaining momentum. Ontological views of Mormons are based not only on the Bible, but on a whole corpus of additional sources and holy writings, which determine the specific features of Mormonism, including its ontological doctrine. The worldviews of Mormons and their way of life, as well as their value orientations and spiritual ideals, are formed according to this doctrine. Therefore, research into such a specific area as the ontological doctrine of the LDS Church is extremely relevant.

The world leaders in the sphere of research into the activities and functioning of the LDS Church institutions are predominantly English-speaking countries, the USA and the UK in the first place. In particular, works by Tanner J., Tanner S. (2007), Bradford M.G. (2007), Davis, S.T. (2007), Smith D.T. (2014), Stone T. (2000) Morality as the enemy of equality: Law, economy, and moral responsibility in the early Mormon church//The Journal of Socio-Economics, vol. 29, issue 1, pp. 57-71 and many others are worth mentioning. The work "What Other Christians Can Learn from the Latter-day Saints" published by Oxford University in 2013 by S.H. Webb (2013) is especially valuable.

The objective of this research is to identify the ontological characteristics of the LDS Church teachings, as well as specific features of its genesis, development and functioning.

The hypothesis of the research is as follows: the specific features of perception of the Trinity in the Mormon doctrine are presented through specific ontological understanding of the nature of God and His materiality; however, the foundation of the ontological doctrine of the LDS Church remains Christian, which allows us to classify Mormons as a Neo-Christian movement.

As a result of the research, is objective has been accomplished and the suggested hypothesis has been proved.

Mormon teachings can be characterized by the following specific ontological features:

- existence of at least several levels of being;

- specific vision of the creation by Mormons, which is similar to that shared by first Christians and Gnostics;

- meanwhile, the foundations of the Mormon ontological doctrine remain Christian.

\section{Methods}

The main research methods used were the following:

- the scientific (religious studies) approach - employed for the analysis of the concept of ontology in its religious dimension;

- the philosophical approach - employed for comparison between the ontological doctrine of the LDS Church and philosophical systems developed by Plato, Aristotle and Leibniz; 
3 | The ontological characteristics of the Church of Jesus Christ of Latter-day Saints

- the theological approach - employed for analysis and identifying characteristics of the ontological aspects of the sacral history of the Universe and mankind from the perspective of Mormonism, as well as such fundamental ontological categories in the doctrine of Mormonism as space, time, matter and movement.

\section{Results}

Ontology is the philosophical study of being as such. It embraces a range of issues that arise in modern philosophy and serves to explain many facts recorded by modern science. It allows people to comprehend many phenomena, the ones that can be observed, as well as those that exist only at the abstract level.

As far as ontology in its religious dimension is concerned, it essentially looks at the being of God, the world and the human. These three elements represent inseparable unity in any ontological component of any religious teaching.

The ontological doctrine of the LDS Church can be characterized in the following way:

- at its core, it is based on the Christian beliefs, namely creation of the world by God, belief in life after death, existence of the Trinity, etc.;

- existence of pre-mortal life in a spiritual body;

- viewing the spirit as a substance that cannot exist without matter; according to the prophets of the LDS Church, "all spirit is matter";

- eternity of a person as a spiritual and material being that had existed in a spiritual body before the creation of the world and its own birth and that will exist eternally;

- nature of Trinity as three separate persons is viewed within the whole process of alignment of the matter, creation of the Universe and human salvation according to the divine Plan of Salvation;

- God the Father (Heavenly Father) and God the Son (Jesus Christ) have perfect physical bodies, which means that they have bodies of flesh and bones. Human beings were created after the image and likeness of God;

- Jesus Christ creates the world at the direction of God the Father;

- Holy Ghost represents spiritual matter, i.e., according to Mormons' teachings, it has a certain fine material body;

- after Satan's rebellion, he was cast out of heaven (a material world of the heavenly body of Kolob) and also became a spiritual substance;

- all angels that fell together with Satan have acquired the same nature;

- future material world will be transformed into three kingdoms (degrees of glory), outside of which, in the world of unorganized matter and chaos (outer darkness), all eternal spiritual substances that were not able to enter any of the kingdoms for their deeds will reside.

The doctrine of the LDS Church contains a few theories: the theory of pre-mortal life, the one of salvation, creation of the world and future life after death and transformation of the world into three kingdoms. It considers the nature of God, His existence in a material body in the Kolob 
system, the structure of the earthly world (including our material Universe), spiritual dimensions of the parallel world and the ontology of hell (as a state of a soul that resides in a particular place).

In order to comprehend such key categories of philosophical ontology as being, essence, existence, matter, movement, space, time and others, as well as their specific features in the teachings of Mormons, it is necessary to reconstruct the sacral history of this denomination as such - not its official and social existence, but its metaphysical being Comparative analysis of the role of religious traditions in the moral self-determination of believers of the Abrahamic religions (using the example of Islam and Orthodox Christianity) (Rakimzhanova and Rakymzhanov 2019).

The main sources from holy writings should also be mentioned since they will help to understand how the fundamentals of the LDS Church ontology developed.

Analysis of the Mormons' teachings shows that according to their beliefs, history starts in the heavenly world and has no end since the LDS Church is eternal. Its metaphysical essence looks like a ray of light, which has a beginning, but no end.

The key moments of the sacral history of mankind and the true church of Jesus Christ which the ontological doctrine of Mormonism is based on are the following:

1. The actual start is arguably the Council in Heaven regarding the creation of the world convened by God the Father. The participants of this Council included Heavenly Father himself and Jesus Christ, the savior and the creator of the world. It is important that spirits also took part in the Council - they were future members of the Church who were going to receive material bodies in the future physical world. These issues are described in the Book of Abraham (The Pearl of Great Price, 2004).

2. Jesus Christ created the world first in the spiritual and then in the material being following His Heavenly Father's plan, laws and guidance. The first people communicated with God but lost this connection as their fall from grace and spiritual death started. It was a part of the Plan of Salvation. Later God came in revelations only to the righteous and prophets. These events are depicted in the Book of Moses (The Pearl of Great Price, 2004).

3. During the construction of the Tower of Babel, all people were frustrated since they did not understand each other's languages. With a group of the righteous people, Jared emigrated to the American continent. It was the first migration to the location of the renewed church. At this time, about $3000 \mathrm{BC}$, the first proclamation of Jesus Christ took place. Taking into account the civilization of Sumer, the Akkadian Empire and the pre-Sumerian period, Mesopotamia is apparently meant by Babel, where Abraham came from (the Book of Ether - a part of the Book of Mormon). Thus, according to Mormons' teachings, the first proclamation of Messiah happened much earlier than traditional Christians believe, who consider Isaiah to be the first prophet (The Book of Mormon, 2011).

4. Abraham from Ur (a Sumerian town not far from Babel, at that time Chaldean, according to the Bible) left Babylonia in about $1800 \mathrm{BC}$ and ended up in Egypt, where he met pagan priests. There he had a revelation and wrote a book - a papyrus, which came into the hands of Joseph Smith in the first half of the 19th century. The prophet translated the book with the help of the Holy Ghost and the knowledge about the structure and creation of the Universe was revealed to him - this moment is described in the Doctrine and Covenants. (The Doctrine and Covenants of The Church of Jesus Christ of Latter-day Saints, 2011)

5. The emergence of the people that received divine Revelation, whose patriarch was Israel, Abraham's grandson. Jews fell into paganism, which lasted nearly to the fall of Judaea. 
5 | The ontological characteristics of the Church of Jesus Christ of Latter-day Saints

Paganism existed along with monotheism - real monotheism since it was belief in one God, Heavenly Father - creator of the heaven and earth. This period is described in the Book a Genesis, a part of the Old Testament.

6. Enslavement of the Israelites in ancient Egypt, their liberation and, consequently, the second trip to Egypt, as told in the Bible, and receiving Egyptian revelations. This moment is described in the Bible and duplicated in the Mormons' holy writings. (The Pearl of Great Price, 2004; The Book of Mormon, 2011).

7. Destruction of Jerusalem, before which a prophet Lehi and his family left the city around $580 \mathrm{BC}$. The second migration to the American continent described in the Book of Mormon (the First Book of Nephi) (The Pearl of Great Price, 2004).

8. The First Coming of Jesus Christ, His Atonement and foundation of the Christian Church (four Gospels of the New Testament).

9. The Appearance of Christ before the Native American population (the Book of the prophet Alma). (The Book of Mormon, 2011).

10. The Acts of the Apostles, described in the New Testament books.

11. The decline of the Church after the death of Apostles. The period of distorted Christian Church (Joseph Smith - History) (The Pearl of Great Price, 2004).

12. Restoration of the true Christian Church in 1830, i.e. the Church of Jesus Christ of Latter-day Saints (Joseph Smith — History). (Smith 2014).

13. Restoration of the Gospel and its preaching before the Second Coming of Jesus Christ (Joseph Smith - the Doctrine and Covenants). (The Doctrine and Covenants of The Church of Jesus Christ of Latter-day Saints, 2011).

14. The Second Coming of Jesus Christ, beginning of a new millennium. Annihilation of the wicked, binding of Satan, the first and second resurrection - described in nearly all Mormons' holy writings (The Pearl of Great Price, 2004; The Book of Mormon, 2011; The Doctrine and Covenants of The Church of Jesus Christ of Latter-day Saints, 2011).

15. The end of the Millennium. The Final Battle and banishing Satan to outer darkness beyond the Universe - section 76 of the Doctrine and Covenants (The Doctrine and Covenants of The Church of Jesus Christ of Latter-day Saints, 2011).

16. Transformation of the physical world into three degrees of glory - described in the Doctrine and Covenants (The Doctrine and Covenants of The Church of Jesus Christ of Latter-day Saints, 2011).

17. Mankind dwelling in three degrees of glory - celestial, terrestrial and telestial. Lucifer, the army of Satan and all the wicked who do not deserve any degree of glory residing on the boundary between being and nonbeing, in outer darkness. This knowledge is not available to humans though.

18. Development of mankind and the LDS Church in eternal contemplation of God in the presence of Jesus Christ and Holy Ghost - the corresponding statement is featured mainly in the Doctrine and Covenants (The Doctrine and Covenants of The Church of Jesus Christ of Latter-day Saints, 2011).

In the face of God all these things exist at the same time, i.e. they make up the cosmological aspect of existence that reflects the static structure of the Universe, but also unfold 
through time so that they are perceived by spirits and imperfect beings - thus, they see the creation, genesis, decline and restoration of the Universe, i.e. the cosmogonic processes are described. To sum up, it is typical for the modern LDS Church to share the idea of the space-time continuum that explains that "in the face of God everything exists at the same time".

\section{Discussion}

The ontological categories of Mormonism are partially based on Aristotle's metaphysics, where he identifies four causes behind all the change in the world: material, formal, efficient and final.

According to Aristotle, the material cause exists separately from God, God is not its creator, while the other three originate from Him. Matter as such resides in the state of half-being and fulfills itself through actualization-entelechy, i.e. form. God represents absolute being and shapes the forms of matter that emerge in the substrate, i.e. kinds or levels of matter. He initiates motion of such categories as quality, quality and location - for the purposes of their change, transformation and disintegration. Everything has been created by God, each action has its own goal and is expressed by necessity, possibility or chance (Aristotle 1976).

In the theory of Mormonism, there is a concept of initial matter - unorganized chaos and different level of its actualization: spiritual matter, physical matter and matter in telestial, terrestrial and celestial degree of glory, i.e. matter expressed either in eternity or immortality. The material cause also exists independently of God, while He represents the other three causes, which are also present in the LDS Church teachings.

The main aspect of comparison between Mormonism and Platonism is the concept of ideas and the theory of gods Demiurge and Futurgos.

Ideas are the elements, which the first spiritual world was made of. It was the prototype for the material world, however, from the Mormons' perspective, the physical world is better than the spiritual one, while in Plato's theory the situation is the opposite. He represents the physical world only as a play of shadows. Heavenly Father is Futurgos, ultimate Good and Jesus Christ is Demiurge, who creates the world according to the ideas.

However, new religions were not content with traditional ontological religious doctrines based on Aristotle's metaphysics and partially on the ideas of Platonism. Combining the ontological concepts and abstract logical forms with the language of religion, the newest movements modernized old theological doctrines. Therefore, the knowledge acquired through philosophical reflections was reflected in an accessible religious figurative form. It encouraged the large-scale distribution of this knowledge since it became easier to understand and perceive for average people.

Among other philosophical ideas, the Neo-Christian movements (the ones that emerged on the basis of Christianity in the 19-21st centuries) tend to accept the ideas of monads most of all, as eternal, not created but existing since the dawn of time spirits originating from God - it is this vision that was reflected in the ontological religious doctrine of the LDS Church. According to Mormons' teachings, these spirits are primary, i.e. eternal. Before the material world was put in order, they had no bodies but existed in the form of some "fine" matter. Thus, the Mormon doctrine says that existence cannot be only spiritual - it must have an indirect connection with matter. God, Jesus Christ and Satan, on the contrary, had perfect bodies. 
According to Mormons' teachings, organization of the universe by Jesus Christ (namely organization, since matter is eternal and separate from mind, it has not been created by God) was an act of creation. It was necessary for the spirits of people to obtain material bodies; however, material earthly bodies are not perfect - they are only intermediate links in the evolution of spirit materialization. After death, human beings spend a short time in the parallel spiritual (the least material) world, after which they receive bodies as perfect as their spirits are.

It is evident that in their theology, Mormons distinguish spirit (substance with its own being) that is eternally connected with a spiritual body. This body is primary and real, it allows spirit to be actualized in matter and have a body or reside "in the presence of God" and receive grace, but it is deprived of spiritual and material development. If there is neither a material body nor the presence of God, hell begins, because everything is possible in a spiritual body, which has no matter to put obstacles in the way of evil and there is no God either who could save and protect. In the Mormon doctrine, deprivation of a material body is a terrible punishment.

Therefore, logical parallels can be drawn between the Mormon doctrine and Leibniz's monadology: eternal existence and the non-created nature of monads and spirits; both groups originate from God; they need matter for actualization; they exist at different levels of material organization. According to this philosophy, a human body consists of ten thousand elements that contain monads (souls). There are three types of monads: plants, animals (souls) and humans (spirits, including those that have not been embodied yet). A human body is a complex mechanism that is managed by a certain control center that exists objectively and autonomously from an individual human monad. What a person calls self and perceives as self is their monad. It has independent existence and is a separate substance, but cannot exist without matter (Leibniz 1982).

According to Leibniz, matter is a raw passive category that does not have its own being; it possesses some attributes, the main of which is its extension. Matter encourages actualization of monads but is not their source (Leibniz 1982).

A monad itself is immortal, but it originates from God. It cannot be subject to decay or decomposition into constituent elements since it is a simple indivisible substance. A monad is influenced by the level of its perception and, as a result, its self-awareness and the qualitative composition of the material body it is connected with.

The Leibniz's monad is the spirit the whole Mormon theology alludes to, which was not able to separate it from the spiritual body.

Mormon monotheism has its own specific features that can be explained by the fact that the LDS Church originated in the Protestant environment. God is the reason for any being, but He does not represent absolute being.

The criticism and accusations of polytheism against Mormons are based primarily on the attitude of the LDS Church believers to God and distortions of the interpretation of the term "gods". Traditional Christian researchers associate the term "God" with totally different concepts and meaning from those understood by Mormons. Another significant controversial point is the nature of the Trinity: Mormons deny the doctrine of "triunity". In the teachings of Mormons, God the Father, God the Son and God the Holy Ghost are three different persons, while in traditional Christianity there is only one God - Heavenly Father, the Creator and the head of material and spiritual Universe. Therefore, the monotheism of the LDS Church is quite a specific phenomenon. However, Mormons clearly state that they are monotheists and believe in one God and worship Him by making Covenants with Him in their churches. 
In the course of the general analysis of the LDS Church doctrine, it is impossible to avoid the issue of evil and its genesis, which is one of the central problems of modern Western Christianity in general and Mormonism in particular.

In the Mormon doctrine the dualism between good and evil, God and Devil, is overcome by not quite a traditional way, since the figure of the devil is not only equal to God but also resides at another level of being.

The fall from grace of Lucifer, son of God, who wanted to be a creator, happened at the point of creation of the world, when Jesus, "similar to Son of Man", received the authorization for creation. Christ became the Demiurge, basically Jehovah of the Old Testament, and consequently the Savior, who leads to transformation of the Universe. Lucifer became Satan and lost his perfect material body because of the rebellion he had started; he was cast out of heaven in his spiritual body and became the evil of the Universe. Since Satan is immortal, at the end of time, he will be cast out beyond the boundaries of the Universe into outer darkness, which represents rare protomatter.

After the death of the physical body, the human shifts to a spiritual body. Depending on the level of their piety and righteousness, until their resurrection they will reside either in Paradise or Spirit Prison, which are in fact states that this person worked themselves into during their life rather than specific places. Spirit Prison is not eternal torture or punishment but a temporary measure for purification, studying the Holy Scripture and cognition.

Depending on their righteousness, the human physical body will be transformed into one of the three degrees of glory, which as actually certain dimensions that exist in parallel with the world. These dimensions are hierarchical from less perfect to the most perfect, but matter will be different there and all bodies will become immortal and imperishable. Only the worst people (such as Cain) will be cast out to outer darkness together with Satan.

It should be mentioned that physical and ontological space and time are totally different things. While the physical categories relate to material objects, without which they do not exist, the ontological definitions are abstract comprehensive concepts, which imply that space and time are of absolute quality.

Emphasizing the material nature of all objects, Mormon ontology reduces them to physical correlation, i.e. it specifies the source of their movement, extension in space and existence in time connected with changes in their state. However, at the same time absolute (ontological) time also exists, as well as space, in which the whole of material and non-material worlds is located since there is movement too.

These objects and, consequently, material worlds, are viewed in the context of physical time when they are interrelated by creation, changing and development, as well as in the context of absolute (ontological) time when everything exists at the same time in the face of God.

A stand-alone point of Mormonism is unorganized matter of chaos, which is actually only proclaimed but not defined in this doctrine. It suggests that this matter exists on the boundary between being and nonbeing, where everything is expressed by actualization in the course of an external act, for example, an act of God. It should be noted that the potential substances (spirits) that reside in this sphere cannot self-actualize and can be translated into the sphere of being only by someone's will. 
9 | The ontological characteristics of the Church of Jesus Christ of Latter-day Saints

\section{Conclusion}

Analysis of the Mormon doctrine shows that there are at least several levels of being, from full actualization of God the Father to virtual nonbeing as existence of non-material objects in chaos. Consequently, there are several levels of matter - from celestial completeness to unorganized matter of chaos. Description of the sacral history of mankind and the Universe based on the research into holy writings of Mormons shows specific vision of the creation by Mormons, which is similar to that shared by first Christians and Gnostics. However, in spite of this, the foundation of the ontological doctrine of the LDS Church remains Christian, which allows us to classify Mormons as a Neo-Christian movement.

Therefore, the hypothesis of the research has been confirmed: the specific features of perception of the Trinity in the Mormon doctrine are presented through a specific ontological understanding of the nature of God and His materiality. However, the foundation of the ontological doctrine of the LDS Church remains Christian, which allows us to classify Mormons as a Neo-Christian movement.

Unfortunately, due to the restriction on the volume of the publication, we had to leave out some issues not directly related to the objective and main direction of the research. In particular, this is the case with fundamental categories in the Mormon doctrine, oncological nature of spiritual matter, degrees of glory and unorganized chaos, history and logic of relations between the LDS Church and religious freedom. The last of these issues can become a direction for future research.

\section{References}

Abylaikhan, S. M., Karmanova, Z. A., Abilkassimova, G. K., Beisenbekova, G. B. and Baizhumanova, N. S. (2019). Forming a Child's Moral Culture in a Multi-confessional Society. European Journal of Science and Theology, 15(3), 133-143

Aristotle (1976). Metaphysics. Collected works in four volumes, vol. 1. Moscow: Mysl, pp. 550.

Bradford, M. G. (2007). The Study of Mormonism: A Growing Interest in Academia. Review of Books on the Book of Mormon 1989-2011, 19(1), 119-174.

Davis, S.T. (2007). Philosophical Theology for Mormons: Some Suggestions from an Outsider. Element. Spring \& Fall, 3(1\&2), 93-105.

Leibniz, G. W. (1982). Monadology. Collected works in four volumes, vol. 1. Moscow: Mysl, pp. 636.

Rakimzhanova, S. K. and Rakymzhanov, B. K. (2019). Comparative analysis of the role of religious traditions in the moral self-determination of believers of the Abrahamic religions (using the example of Islam and Orthodox Christianity). European Journal of Science and Theology, 15(2), 19-30.

Šindleryová, I.B. and Bačuvčík, R. (2019). Dreams and reality church versus target groups. European Journal of Science and Theology, 15(1), 47-59.

Smith, D.T. (2014). The Mormon dilemma: How old and new religious divides hurt Mormon candidates in the United States. Electoral Studies, 35, 283-291.

Stone, T. (2000). Morality as the enemy of equality: Law, economy, and moral responsibility in the early Mormon church. The Journal of Socio-Economics, 29(1), 57-71.

Tanner, J. and Tanner, S. (1994). The Changing World of Mormonism. "A condensation and revision of Mormonism: Shadow or Reality?” United States: Moody Press, pp. 591 
The Book of Mormon. Another Testament of Jesus Christ. (2011). Salt Lake City: Intellectual Reserve, Inc., pp. 203.

The Doctrine and Covenants of The Church of Jesus Christ of Latter-day Saints. Teacher Manual. An indepth study of the Doctrine. (2011). Salt Lake City: The Church of Jesus Christ of Latter-day Saints, pp. 186.

The Pearl of Great Price. Student Manual. Religion 327. (2004). Belgium: Intellectual Reserve, Inc., pp. 98.

Webb, S.H. (2013). Mormon Christianity: What Other Christians Can Learn From the Latter-day Saints. 1st Edition. Oxford: Oxford University Press, pp. 217. 